\title{
DIC IN VALIDATION OF BOUNDARY CONDITIONS OF NUMERICAL MODEL OF REINFORCED CONCRETE BEAMS UNDER TORSION
}

\author{
B. TUROŃ ${ }^{1}$, D. ZIAJA ${ }^{2}$, L. BUDA-OŻÓG ${ }^{3}$, B. MILLER ${ }^{4}$
}

\begin{abstract}
The paper presents the experimental research and numerical simulations of reinforced concrete beams under torsional load. In the experimental tests Digital Image Correlation System (DIC System) Q-450 were used. DIC is a non-contact full-field image analysis method, based on grey value digital images that can determine displacements and strains of an object under load. Numerical simulations of the investigated beams were performed by using the ATENA 3D - Studio program. Creation of numerical models of reinforced concrete elements under torsion was complicated due to difficulties in modelling of real boundary conditions of these elements. The experimental research using DIC can be extremely useful in creating correct numerical models of investigated elements. High accuracy and a wide spectrum of results obtained from experimental tests allow for the modification of the boundary conditions assumed in the numerical model, so that these conditions correspond to the real fixing of the element during the tests.
\end{abstract}

\footnotetext{
${ }^{1}$ MSc., Eng., Rzeszow University of Technology, Faculty of Civil and Environmental Engineering and Architecture, Poznańska 2, 35-084 Rzeszow, Poland, e-mail: bturon@prz.edu.pl

${ }^{2}$ MSc., Eng., Rzeszow University of Technology, Faculty of Civil and Environmental Engineering and Architecture, Poznańska 2, 35-084 Rzeszow, Poland, e-mail: dziaja@prz.edu.pl

${ }^{3}$ PhD., Eng., Rzeszow University of Technology, Faculty of Civil and Environmental Engineering and Architecture, Poznańska 2, 35-084 Rzeszow, Poland, e-mail: lida@prz.edu.pl

${ }^{4}$ DSc., PhD., Eng., Rzeszow University of Technology, Faculty of Civil and Environmental Engineering and Architecture, Poznańska 2, 35-084 Rzeszow, Poland, e-mail: bmiller@prz.edu.pl
} 
Keywords: Digital Image Correlation, DIC, non-contact measurement, concrete, torsion, shear

\section{INTRODUCTION}

The phenomenon of torsion can be observed in many Reinforced Concrete (RC) elements such as: spatial frame structures, stairs, spiral ramps, balcony slab ring beams, extreme beams and arch beam loaded perpendicularly to their plane. Experimental and theoretical research of RC elements under torsional loads started at the beginning of 20th century [10]. The research was carried out intensively in the 1960s and 1970s [14, 19]. However, the research and analyses do not allow for a full description of this phenomenon in reinforced concrete, and the rules proposed in EC2 [8] for the calculation of the ULS and SLS seem to be incomplete. The reason for this is the complicated nature of the phenomenon and difficulties associated with the implementation of experimental studies. Structural elements subjected to torsional load work in the spatial state of stress and strain. Experimental research is mostly conducted on elements in the natural scale and requires dedicated positions and test equipment.

Alternative and easier method can be numerical simulations, whose development in the process of analysis and design of engineering structures has occurred in recent years. The Finite Element Method (FEM) is the most popular of all numerical methods. The dynamic development of computer techniques allows for nonlinear analyses of reinforced concrete elements with special regard payed to non-linearity of material, the real arrangement of steel rebars in element and the mechanisms of failure [13]. Despite this, the numerical model of reinforced concrete elements under the torsional load is still not enough recognized. The results obtained from numerical models are not always compatible with the results of experimental studies. The reasons for this are: difficulties in modeling failure mechanisms of concrete in the biaxial stress state and problems with real modelling of boundary conditions of these complicated elements.

The aim of the presented work is validation of boundary conditions of numerical models of reinforced concrete cantilever beams subjected to combined bending, shear and torsion. The validation is carried out on the basis of data obtained from the experimental research carried out with the use of the Digital Image Correlation system. 
Digital Image Correlation (DIC) is a non-contact, full-field image analysis method, based on grey value digital images. This method allows for determination of the displacements and strains of the investigated objects, in both two-dimensional (2D) and three-dimensional (3D) spaces on the basis of high-resolution images that are recorded during the change of the location or shape of the examined objects. This method is based on advanced opto-electronic systems, that include high-resolution cameras as well as high-speed cameras that allow the recording of the images during fast-changing events $[5-7,11,15,18]$.

The method was introduced to experimental mechanics in the late eighties by a group of researchers from the University of South Carolina [4]. This method can be applied for both laboratory and in-situ measurements. It has a lot of advantages, for instance: non-contact and full-field measurement, simple lab set-up, easy preparation of the investigated object. The DIC method provides a wide range of measurement sensitivity and resolution. It has various applications such as: structural analysis of welded joints, tests of objects during the fracture process, measurement of the surface vibrations, detection of damage in joints of steel structures [7, 12, 17].

\section{INVESTIGATED OBJECTS}

The subject of research and analysis were reinforced concrete cantilever beams made of concrete C35/45 [2]. The beams were reinforced with $\phi 16 \mathrm{~mm}$ and $\phi 10 \mathrm{~mm}$ bars of B500SP steel longitudinal reinforcement and $\phi 6 \mathrm{~mm}$ or $\phi 8 \mathrm{~mm}$ stirrups. The test beams were made in the commercial prefabrication plant "SOLBET". Compressive strength of concrete, tension strength of concrete and modulus of elasticity were measured on standard samples formed for concrete mix of which the beams were made.

The geometry of the tested beams and their structure diagram of fixing are shown in Fig. 1 . 


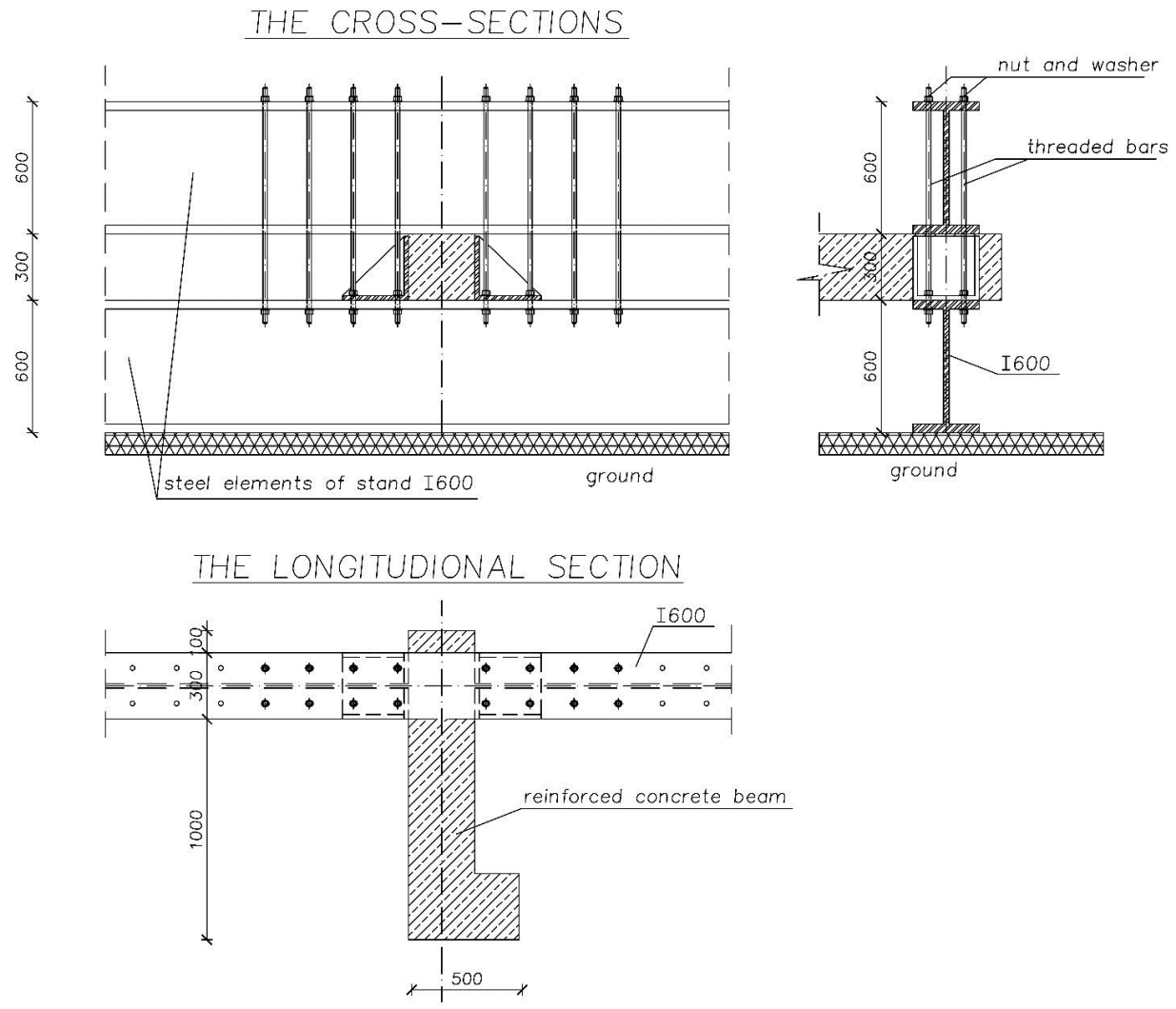

Fig. 1. Beam support scheme

In the initial assumption tested beams were supposed to be fixed at the one end with the second end left free. During the tests, due to inaccurate fabrication of the beams and small displacements at joint between beam and steel elements, this assumption has not been fulfilled.

\section{EXPERIMENTAL TEST BY USING DIGITAL IMAGE CORRELATION}

The aim of the experimental research was to obtain data for validation of numerical models of reinforced concrete beam working in a compound stress state. The research program included measurement of the three reinforced concrete cantilever beams with the use of the DIC system. The experimental research was carried out in the accredited testing laboratory at the Faculty of Civil and Environmental Engineering and Architecture of Rzeszow University of Technology. 
In tests 3D DIC System Q-450 from Dantec Dynamics was used. The main elements of this system are two digital cameras Phantom v341, characterized by a resolution of $4 \mathrm{Mpx}$ (maximum image resolution is $2560 \times 1600 \mathrm{px}$ ) and a laptop with software Istra 4D. The other elements of the system are the trigger-control device Timing Hub synchronizing the measuring system, calibration targets and lighting elements $[9,16]$.

The measurement with the use of the Q-450 system consists of the following stages $[9,16]$ :

- object preparation for the test by applying a white base layer to the test surface, and then making a stochastic point pattern on it, for instance by spraying;

- preparation of the test stand and setup hardware;

- system calibration by using calibration targets;

- test measurement, the aim of the test is to select properly the measurement parameters;

- proper measurements i.e. image acquisition during loading of the object;

- analysis of saved photos which is based on correlation, this is called the evaluation process;

- visualization of the obtained results.

By means of the Q-450 system, during the entire loading cycle, displacements and strains were measured on the selected beam surface. DIC system measurements were made on the beam side surface from its bending side. The area selected for testing was approximately $600 \mathrm{~mm}$ x $300 \mathrm{~mm}$ (see Fig. 2a). The surface of the beam selected for tests was cleaned, then white paint was applied on the surface, creating a base layer, finally a random pattern of black spots was applied on white layer by spraying (see Fig. 2b). The density of the pattern has been adapted to the size of the area under investigation.

a)

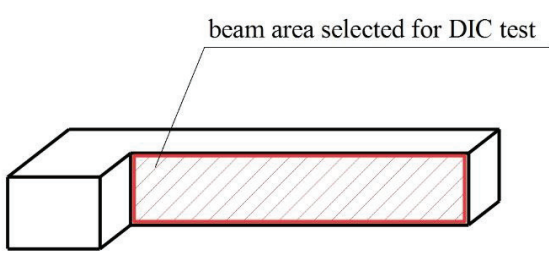

b)

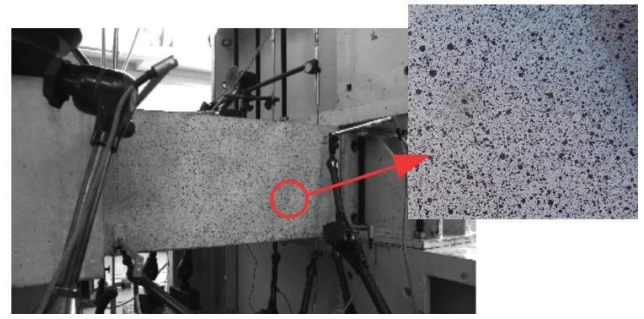

Fig. 2. Investigated fragment of the beam: a) the area selected for study, b) random points pattern on the tested surface 
The beams were subjected to static loading. The force was increasing in increments of $5.0 \mathrm{kN}$ up to about $60 \%$ of failure load $-\mathrm{F}_{\max }$ and when the loading level $\mathrm{F}_{\mathrm{i}}=0.6 \mathrm{~F}_{\max }$ was achieved, the beam was loaded in increments of $2.0 \mathrm{kN}$ until its failure.

The recording of images of loaded elements was carried out continuously at frequency of $1 \mathrm{~Hz}$. The test stand consisted of the Instron-Schenck system and the Dantec Dynamics Q-450 system equipped with two cameras. The measurement set-up prepared for research is shown in Fig. 3.
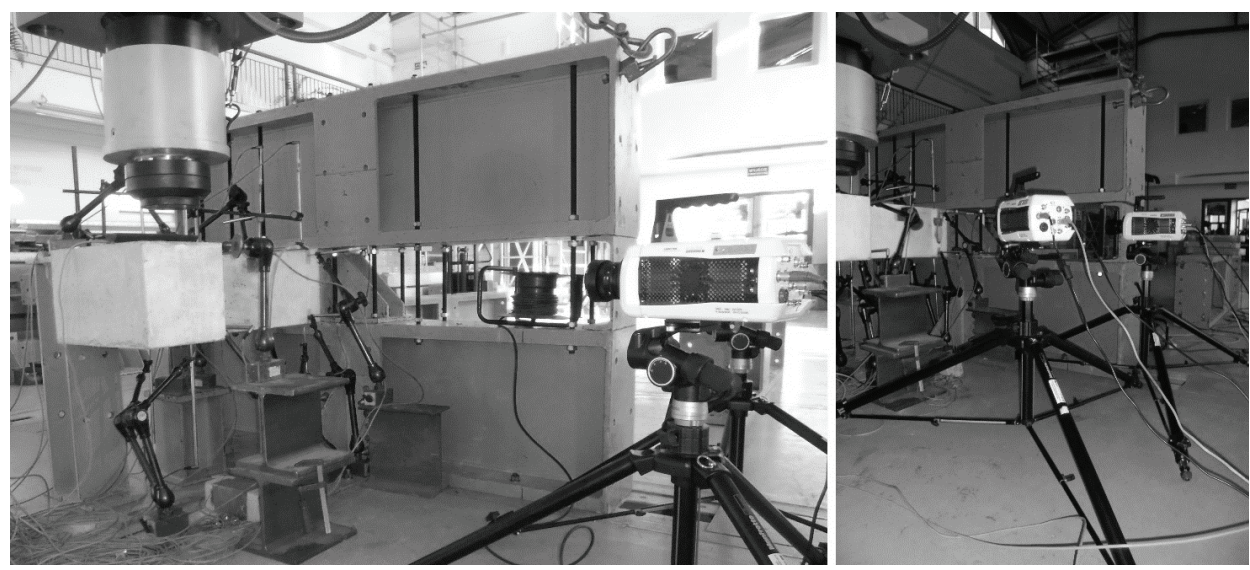

Fig. 3. Measurement set-up

The vision system Q-450 enabled simultaneous measurement of displacements of 2500 points located on the side surface of the beam (see Fig. 4).

The use of the DIC system in research of cantilever reinforced concrete beams allowed to:

- the measurement of displacement in three-dimensional space i.e. on the investigated surface of the beam and perpendicular to this surface at every second of the test (see Fig. 5),

- the observation of the development of cracks on the examined beam surface during the test, the determination of the cracks course and the measurement of their inclination angle, before the cracks were visible to the naked eye,

- the measurement of strains (main strain, shear strain) at every second of the test,

- the measurement of deflections along the beam length, defining the deflection line in each second of the test.

The use of the DIC system in experimental tests of reinforced concrete beams allowed to obtain a series of data that can be used to validate numerical models of the examined objects. 


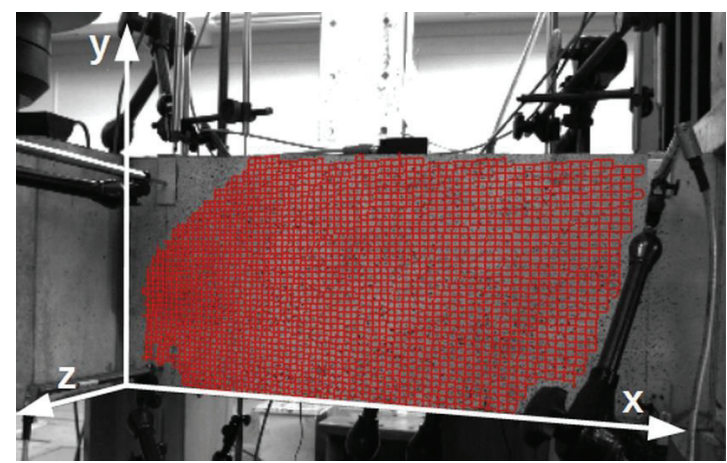

Fig. 4. Measurement points on the beam surface in the xyz coordinate system
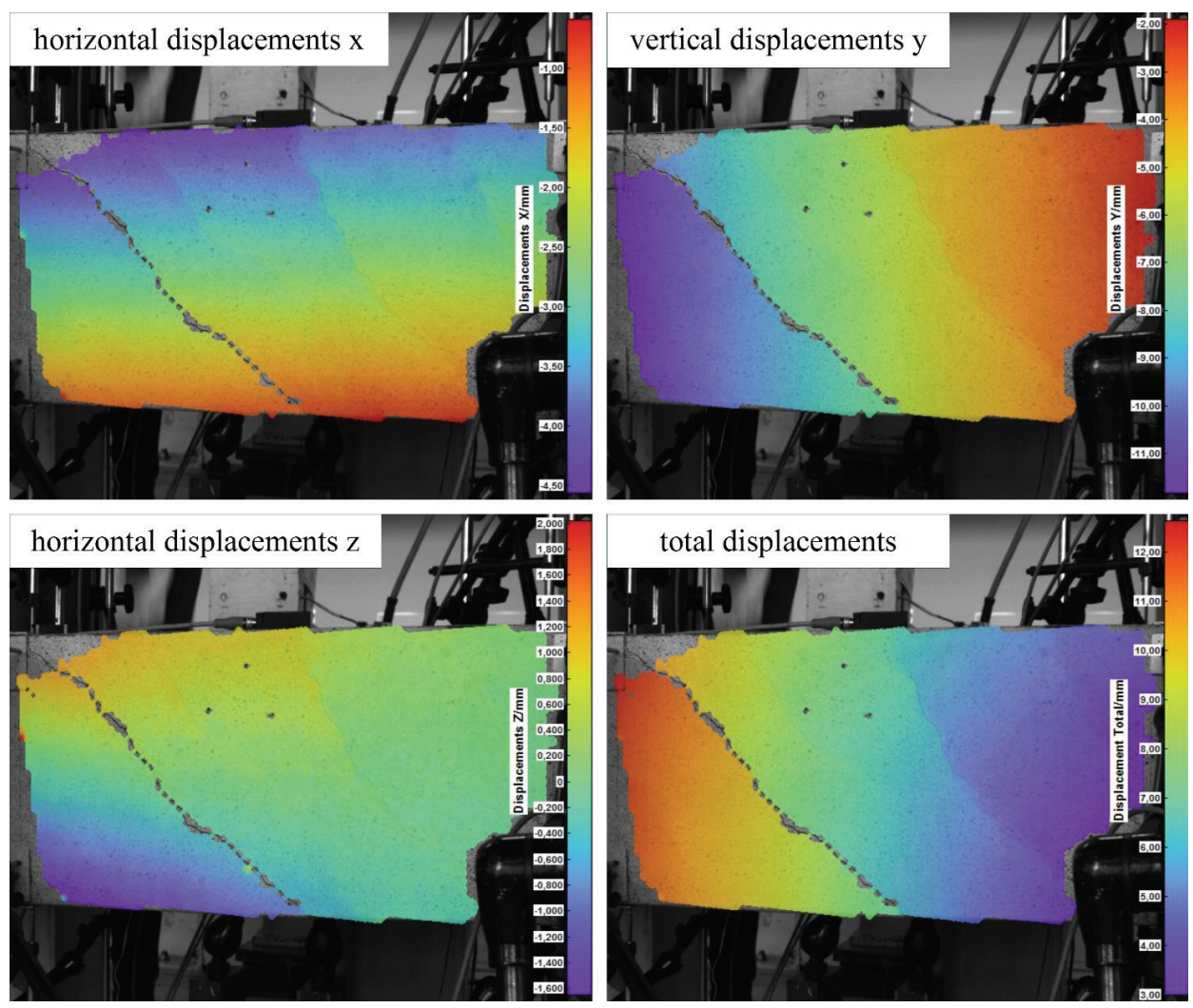

Fig. 5. Displacements obtained at the end of the DIC test 
For tested cantilever reinforced concrete beams, points and linear elements were defined in the Istra 4D program. An exemplary localization of the elements is shown in Fig. 6. The following elements on the beam surface were defined: a horizontal element along the bottom edge of the beam, a vertical element at a distance of $20 \mathrm{~cm}$ from the edge of the beam in the place of its bending, a vertical element at a distance of $15 \mathrm{~cm}$ from the edge of the beam at the place of its fixing, the point $\mathrm{A}$.

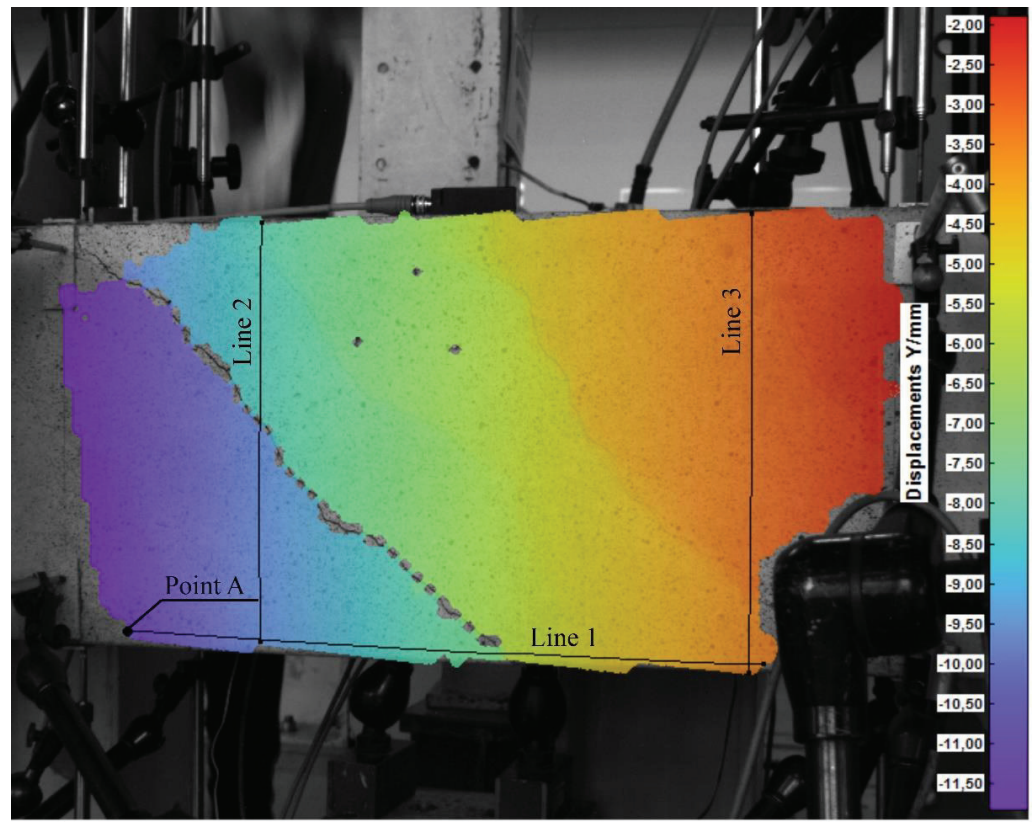

Fig. 6. Point A and linear elements defined on the beam surface

For a point selected on the surface of the beam, its location and values of displacements and deformations can be determined at every second of the research. Defining a linear element allows the analysis of displacements and deformations along the length of this element at every second of the experimental tests. Therefore, the determination of the horizontal linear element gives the possibility of a detailed analysis of the beam deflection during the test, as shown in Fig. 7. The graph shows the values of vertical displacements along the beam length in the following minutes of the test. 


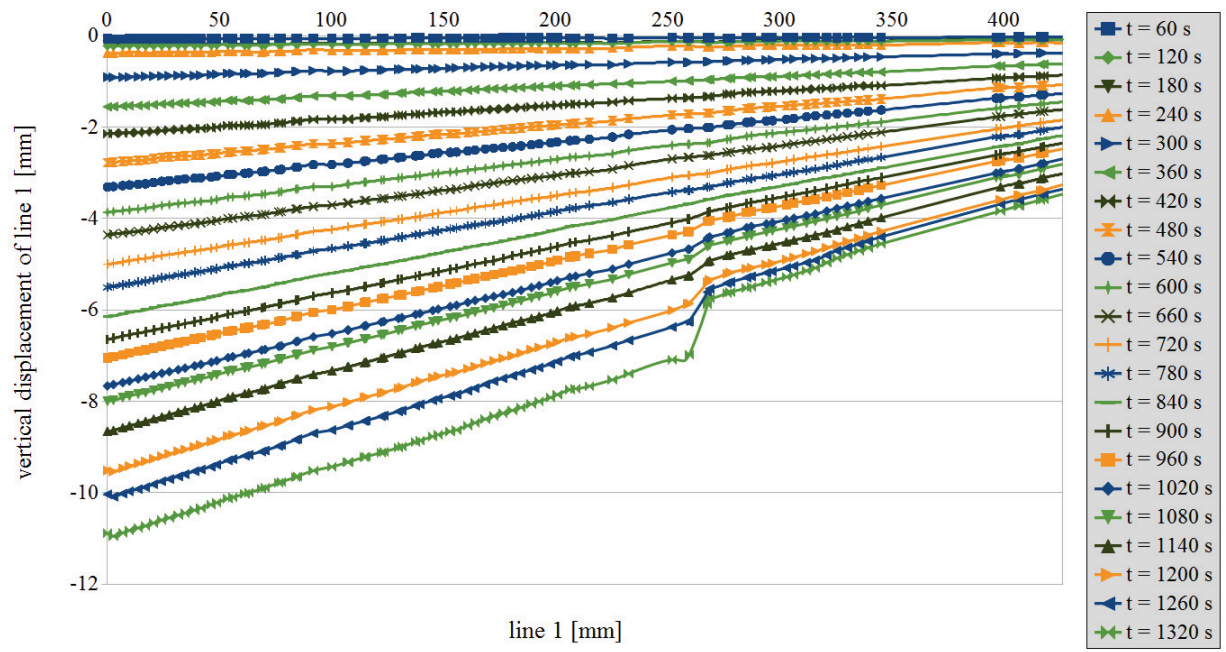

Fig. 7. Diagram of the beam deflection along the line 1 in every minute of the DIC test

\section{NUMERICAL ANALYSIS}

Due to the considerable variability of the concrete properties, the performance of experimental tests on a small sample does not give a full information about the phenomena occurring in the tested element. The alternative may be numerical simulations taking into account the variability of concrete parameters recommended in the literature.

In this study, the simulation of reinforced concrete beam behaviour was performed by using the ATENA 3D - Studio program [1]. For non-linear analysis of reinforced concrete beams, concrete model describing the dependence of stress-strain in the biaxial stress state, were used. The material model includes the following effects of concrete behaviour [1]:

- the non-linear behavior in compression including hardening and softening;

- fracture of concrete in tension based on the nonlinear fracture mechanics;

- biaxial strength failure criterion;

- reduction of compressive strength after cracking;

- tension stiffening effect;

- reduction of the shear stiffness after cracking;

- two crack models: fixed crack direction and rotated crack direction. 
The model of material was adopted by constitutive characteristics obtained from experimental tests. For modeling the main reinforcement, the material model "reinforcement", proposed by ATENA was used. The model of elastic-plastic material, with characteristics corresponding to steel RB500W, was used. To solve static problems of reinforced concrete beam, calculation procedure based on arc-length iterative method was applied $[1,3]$. The method had been verified in the spatial models of reinforced concrete members with concrete crushing and stiffening.

The interface elements are used to model a contact between beam and steel support elements. The interface is defined by a surfaces in 3D. In the original (i.e. undeformed) geometry, the interface surfaces can share the same position or they can be separated by a small distance. In this case we speak about the interface with nonzero thickness.

The interface material is based on Mohr-Coulomb criterion with tension cut off. The constitutive relation for a general three-dimensional case is given in terms of tractions on interface planes and relative sliding and opening displacements [1]:

$$
\left\{\begin{array}{c}
\tau_{1} \\
\tau_{2} \\
\sigma
\end{array}\right\}=\left[\begin{array}{ccc}
K_{t t} & 0 & 0 \\
0 & K_{t t} & 0 \\
0 & 0 & K_{n n}
\end{array}\right]\left\{\begin{array}{l}
\Delta v_{1} \\
\Delta v_{2} \\
\Delta u
\end{array}\right\}
$$

where:

$\Delta v_{1}, \Delta v_{2}, \Delta u$ - relative displacements of the interface sides (sliding and opening displacements of the interface) in the local coordinate system; $K_{t t}, K_{n n}$ - the shear and normal stiffness, respectively. This coefficient can be regarded as stiffness of one material layer (real or fictitious) having a finite thickness. It should be understood that the layer is only a numerical tool to handle the gap opening and closing; $\tau_{1}, \tau_{2}, \sigma$ - shear and normal stresses.

In FE model of the beam the spring elements ware used to model spring-like boundary conditions.

Fig. 8 presents the numerical model of the analysed beam. The boundary conditions and properties of spring are shown in Fig. 9a. The location of the interface element and some properties of the interface material are shown in Fig. 9b. The spring properties in boundary conditions and the interface material were determined on the basis of displacements from measurements carried out using DIC. The analysed beam model was loaded by forces of values corresponding to the experimental tests. 

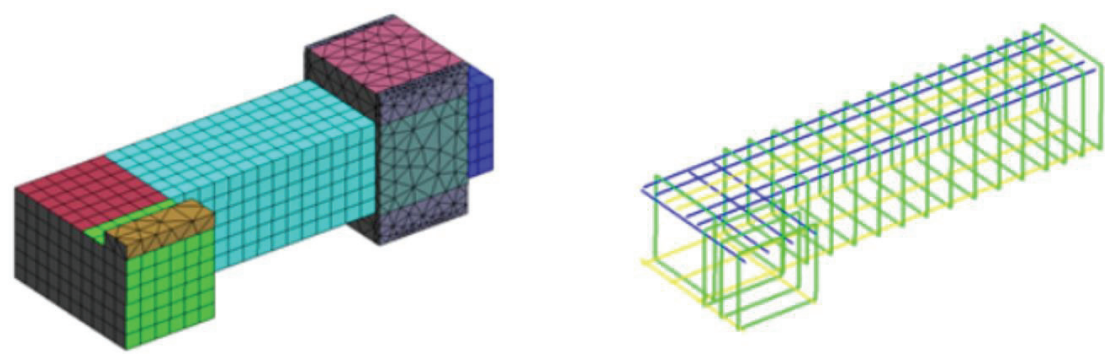

Fig. 8. Numerical model of the beam
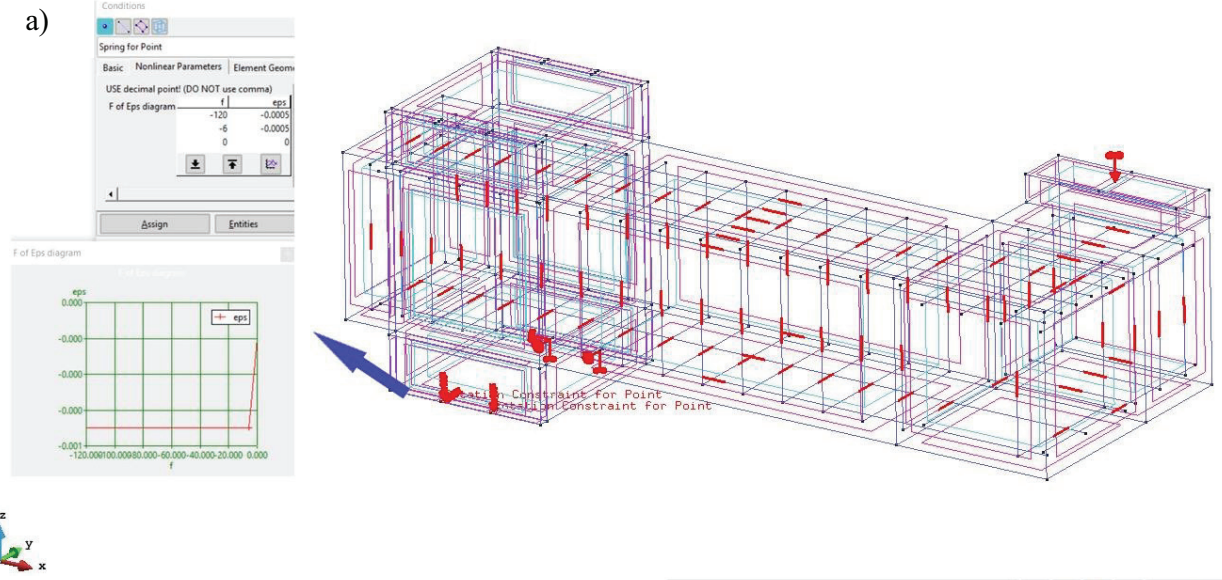

b)

$\log _{-x}^{x}$

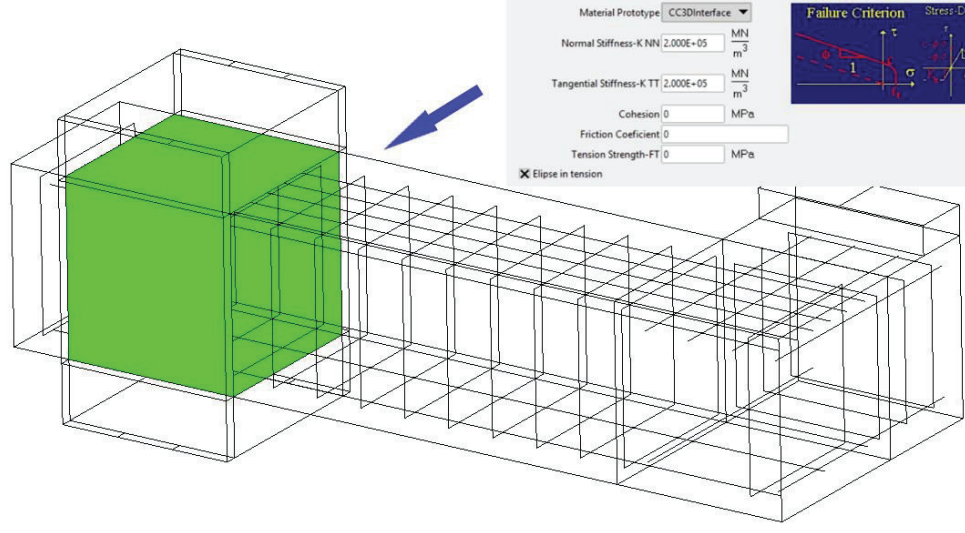

Fig. 9. Numerical model: a) boundary conditions and properties of spring, b) location of the interface element and some properties of the interface material 


\section{VALIDATION RESULTS}

A comparison of selected results obtained from numerical simulations and from experimental data are shown in Fig. 10 through 13. The location of selected points and lines, for which the detailed results are presented, is marked in Fig. 6.

The curve load-deflection plot obtained from the FEA for point A is shown in Fig. 10. The curve agrees accurately with the experimental data.

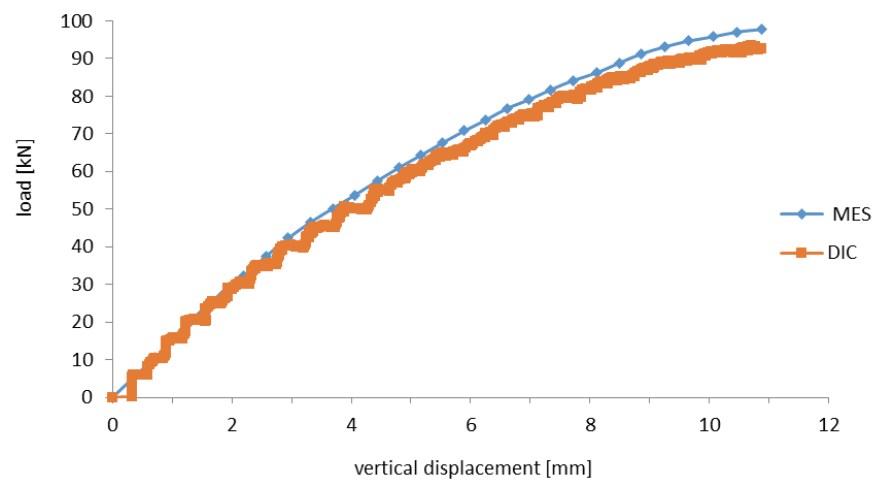

Fig. 10. Load - vertical displacements for the point A, FEM simulations and DIC test

Comparison of displacements from numerical simulation and experimental tests carried out using the DIC system of points along lines 1,2 and 3 are shown in Fig. 11, 12 and 13. These are displacements obtained for the maximum measured forces. Fig. 11 presents vertical displacements from FEM simulations and experimental test for horizontal line 1.

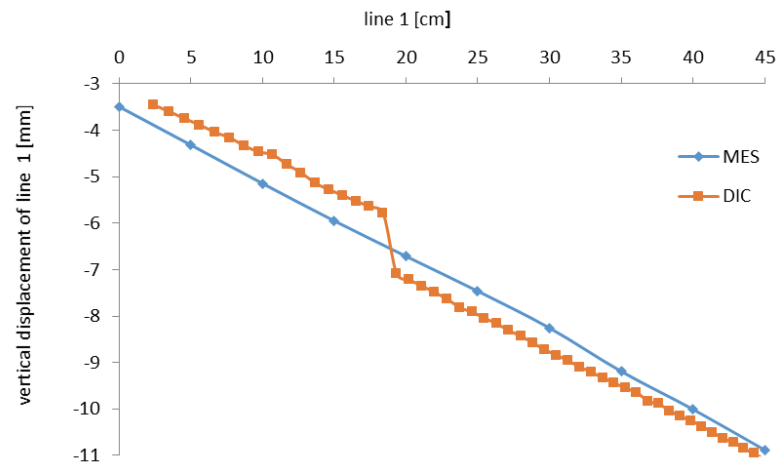

Figure 11. Vertical displacements for the line 1, FEM simulations and DIC test 
Fig. 12 shows the horizontal displacement perpendicular to the plane of the beam, along a vertical line 2, caused by torsion. Fig. 13 presents horizontal displacement in the direction of the beam axis, along a vertical line 3 , caused by the slide out of the beam from the fixing.

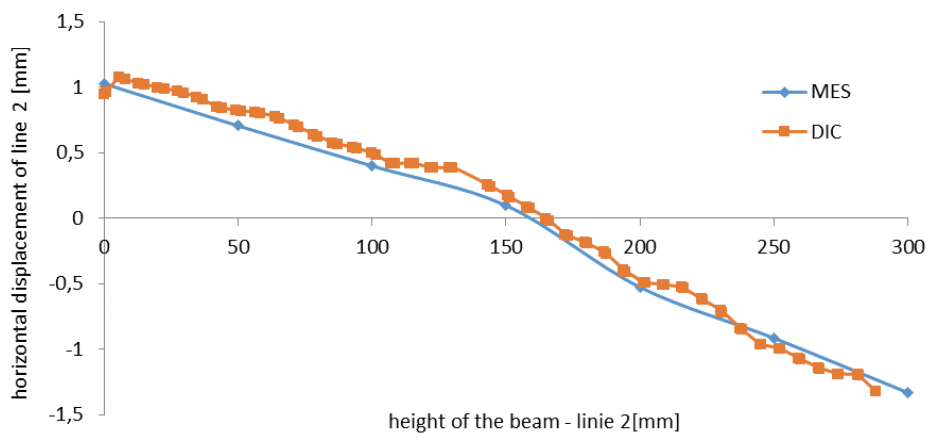

Figure 12. Horizontal displacements perpendicular to the plane of the beam for the line 2, FEM simulations and DIC test

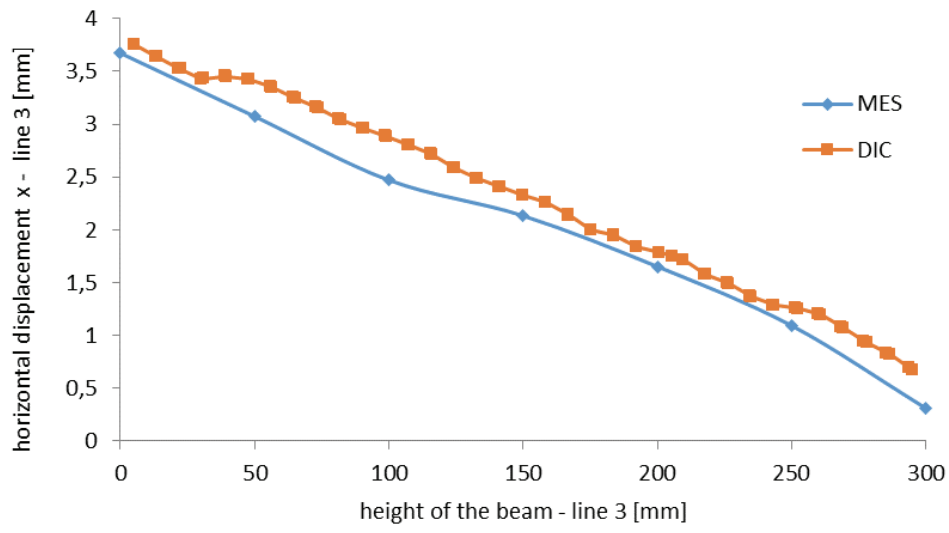

Figure 13. Horizontal displacements in the direction of the beam axis for the line 3, FEM simulations and DIC test

As shown in Fig. 10 to 13, the displacements in three directions obtained from numerical simulations agrees precisely with the results obtained from experimental research. The small incompatibility can be observed for horizontal displacements along the beam axis caused by the slide out of the beam during the tests. The maximum difference of displacements from simulations and measurements is 
$0.44 \mathrm{~mm}$, i.e. around $14 \%$. However, taking into account the coefficients of variation of concrete parameters the numerical simulations and experimental tests are in reasonably good agreement.

\section{CONCLUSION}

On the basis of the experimental research and numerical analyses, the following general conclusion can be formulated:

- The DIC method allows for simultaneous measurements of displacements and strains at many points of the tested objects and it is especially useful in the research of reinforced concrete structure elements which are characterized by high material heterogeneity;

- High accuracy and a wide spectrum of results obtained from experimental tests allow for the modification of the boundary conditions assumed in the numerical model, so that these conditions correspond to the real fixing of the element during the tests.

- If the numerical models are to be an alternative to expensive and labor-consuming experimental research, then due to the complex nature of the phenomenon, experimental validation of numerical models is necessary to obtain correct results describing the ultimate and serviceability limit state in reinforced concrete constructions, and data obtained from measurements carried out with the DIC system are extremely helpful here.

\section{REFERENCES}

1. ATENA Program Documentation, Theory, Praga, 2017.

2. Buda-Ożóg L., "Assessment of Stiffness Beams Subjected to Combined Shear and Torsion Designed Using STM", Procedia Engineering, Vol. 193: 152-159, 2017.

3. Buda-Ożóg L., Skrzypczak I., Kujda J., "Cracks analysis in the reinforced concrete pipes”, The Baltic Journal of Road and Bridge Engineering, Vol. 12, No. 2: 88-93, 2017.

4. Chu T.C., Ranson W.F., Sutton M.A., Peters W.H., "Applications of Digital-Image-Correlation Techniques to Experimental Mechanics”, Experimental Mechanics, Vol. 25, No. 3: 232-244, 1985.

5. Frankovský P., Virgala I., Hudák P., Kostka J., "The use of the Digital Image Correlation in a strain analysis", International Journal of Applied Mechanics and Engineering, Vol. 18, No. 4: 1283-1292, 2013.

6. Hagara M., Huňady R., Lengvarský P., Bocko J., "Numerical Verification of a Full-field Deformation Analysis of a Specimen Loaded by Combined Loading", American Journal of Mechanical Engineering, Vol. 2, No. 7: 307-311, 2014.

7. McCormick N., Lord J., "Digital Image Correlation”, Materials Today, Vol. 13, No. 12: 52-54, 2010.

8. PN-EN 1992-1-1:2008 Eurokod 2 - Projektowanie konstrukcji z betonu - Część 1-1: Reguły ogólne i reguły dla budynków.

9. Q-450 SYSTEM Operation Manual, Dantec Dynamics, 2013.

10. Rausch E., "Drillung (Torsion), Shub and Scheren im Stahlbetonbau", Deutscher Ingenieur Verlag GmbH, Dusseldorf, 1953.

11. Siebert T., Becker T., Splitthof K., "Analysis of advanced materials under load”, SPIE Newsroom, 2006.

12. Sładek J., Ostrowska K., Kohut P., Holak K., Gąska A., Uhl T., "Development of a vision based deflection measurement system and its accuracy assessment", Measurement, Vol. 46, No. 3: 1237-1249, 2013.

13. Słowik M., Smarzewski P., "Numerical modelling of diagonal cracks in concrete beams". Archives of Civil 
Engineering, Vol. 60, No. 3: 307-322, 2014.

14. Thomas T. C. Hsu., "Torsion of Structural Concrete-Interaction Surface for Combined Torsion, Shear, and Bending in Beams Without Stirrups", ACI Journal Proceedings, Vol. 65, No. 1: 51-60, 1968.

15. Trebuňa F., Huňady R., Bobovský Z., Hagara M., "Results and Experiences from the Application of Digital Image Correlation in Operational Modal Analysis”, Acta Polytechnica Hungarica, Vol. 10, No. 5: 159-174, 2013.

16. Turoń B., Ziaja D., Miller B., „Rejestracja i analiza pól przemieszczeń i odkształceń za pomocą systemu cyfrowej korelacji obrazu 3D", Journal of Civil Engineering, Environment and Architecture, Vol. XXXIV, No. 64: 7-28, 2017.

17. Turoń B., Ziaja D., Miller B., „Wykrywanie uszkodzeń węzłów ramy stalowej z wykorzystaniem metody cyfrowej korelacji obrazu", Journal of Civil Engineering, Environment and Architecture, Vol. XXXIV, No. 64: 185-198, 2017.

18. Wang Y. H., Jiang J. H., Wanintrudal C., Du C., Zhou D., Smith L. M., Yang L. X., "Whole field sheet-metal tensile test using digital image correlation", Experimental Techniques, Vol. 34, No. 2: 54-59, 2010.

19. Zia P., McGee W.D., "Torsion Design of Prestressed Concrete”, PCI Journal, Vol. 19, No. 2: 46-65, 1974.

\section{LIST OF FIGURES AND TABLES:}

Fig. 1. Beam support scheme

Rys. 1. Schemat zamocowania belki

Fig. 2. Investigated fragment of the beam: a) the area selected for study, b) random points pattern on the tested surface

Rys. 2. Badany fragment belki: a) powierzchnia wybrana do badań, b) losowy wzór punktów na badanej powierzchni (fot. Barbara Turoń)

Fig. 3. Measurement set-up

Rys. 3. Stanowisko badawcze (fot. Barbara Turoń)

Fig. 4. Measurement points on the beam surface in the xyz coordinate system

Rys. 4. Punkty pomiarowe na bocznej powierzchni belki w układzie współrzędnych xyz

Fig. 5. Displacements obtained at the end of the DIC test

Rys. 5. Wartości przemieszczeń uzyskane z pomiarów systemem DIC w chwili zakończenia badania

Fig. 6. Point A and linear elements defined on the beam surface

Rys. 6. Punkt A i elementy liniowe zdefiniowane na powierzchni belki

Fig. 7. Diagram of the beam deflection along the line 1 in every minute of the DIC test

Rys. 7. Wykres ugięcia belki w kolejnych minutach badania na długości elementu liniowego $\mathrm{nr} 1$

Fig. 8. Numerical model of the beam

Rys. 8. Model numeryczny belki

Fig. 9. Numerical model: a) boundary conditions and properties of spring, b) location of the interface element and some properties of the interface material

Rys. 9. Model numeryczny: a) podpory sprężyste b) lokalizacja i właściwości materiału umownego

Fig. 10. Load - vertical displacements for the point A, FEM simulations and DIC test

Rys. 10. Obciążenie - przemieszczenie pionowe pkt. A, symulacje MES i badania doświadczalne DIC

Fig. 11. Vertical displacements for the line 1, FEM simulations and DIC test

Rys. 11. Przemieszczenie pionowe belki wzdłuż linii nr 1, symulacje MES i badania doświadczalne DIC 
Fig. 12. Horizontal displacements perpendicular to the plane of the beam for the line 2, FEM simulations and DIC test

Rys. 12. Przemieszczenie poziome belki z płaszczyzny belki wzdłuż linii nr 2, symulacje MES i badania doświadczalne DIC

Fig. 13. Horizontal displacements in the direction of the beam axis for the line 3, FEM simulations and DIC test

Rys. 13. Przemieszczenie poziome belki wzdłuż osi belki dla linii nr 3, symulacje MES i badania doświadczalne DIC 


\section{WYKORZYSTANIE METODY DIC DO WALIDACJI WARUNKÓW BRZEGOWYCH MODELU NUMERYCZNEGO ŻELBETOWYCH BELEK SKRĘCANYCH}

Slowa kluczowe: cyfrowa korelacja obrazu, DIC, pomiar bezkontaktowy, beton, skręcanie, ścinanie

\section{STRESZCZENIE}

W artykule przedstawiono badania eksperymentalne oraz symulacje numeryczne żelbetowych belek poddanych skręcaniu. Zjawisko skręcania można zaobserwować w wielu elementach żelbetowych, takich jak przestrzenne konstrukcje ramowe, schody, spiralne pochylnie itp. Pomimo, że badania nad tym zagadnieniem rozpoczęto na początku XX wieku [10] i prowadzono je intensywnie w latach 60 i 70 tych [19] przeprowadzone dotychczas badania i analizy nie pozwalają na pełny opis tego zjawiska w żelbecie, a zaproponowane w EC2 [8] zasady obliczania SGN i SGU wydają się być niekompletne. Powodem tego stanu jest skomplikowany charakter zjawiska i trudności związane z wykonaniem badań doświadczalnych. Badania skręcanych elementów żelbetowych prowadzone są najczęściej na elementach przestrzennych w skali naturalnej i wymagają specjalnie to tego celu wykonanych stanowisk i urządzeń badawczych. Innym a zarazem łatwiejszym rozwiązaniem mogą być symulacje numeryczne, których rozwój w procesie analizy i projektowania konstrukcji inżynierskich, nastąpił w ostatnich latach. Ze wszystkich metod numerycznych najczęściej stosowana jest Metoda Elementów Skończonych. Dynamiczny rozwój technik komputerowych pozwala również na wykonywanie analiz nieliniowych dotyczących żelbetowych elementów konstrukcyjnych ze szczególnym uwzględnieniem zróżnicowanych sprężysto-plastycznych charakterystyk materiałowych betonu i stali, rzeczywistego układu zbrojenia, wzajemnej współpracy obu materiałów oraz symulacji mechanizmu zniszczenia elementów. Pomimo to modelowanie elementów żelbetowych zginanych, skręcanych i ścinanych ciągle nie jest dość dobrze rozpoznane, a uzyskiwane z modeli numerycznych wyniki nie zawsze są zgodne z wynikami badań doświadczalnych. Spowodowane to jest dwoma czynnikami tj.: trudnościami w modelowaniu mechanizmów zniszczenia betonu w złożonym stanie naprężeń oraz problemami związanymi z pełnym odwzorowaniem warunków brzegowych tych dość skomplikowanych elementów.

Celem niniejszej pracy jest walidacja warunków zamocowania modeli numerycznych wspornikowych belek żelbetowych jednocześnie zginanych, ścinanych i skręcanych, na podstawie danych uzyskanych z badań doświadczalnych, przeprowadzonych za pomocą systemu cyfrowej korelacji obrazu. W badaniach doświadczalnych wykorzystano system cyfrowej korelacji obrazu Q-450 firmy Dantec Dynamics. Cyfrowa korelacja obrazu, często określana skrótem DIC (z ang. Digital Image Correlation), jest bezkontaktową metodą pomiarową. Pozwala ona na określenie przemieszczeń i odkształceń badanych obiektów, zarówno w przestrzeni dwuwymiarowej, jak i trójwymiarowej, na podstawie zdjęć wysokiej rozdzielczości, które zostały zarejestrowane podczas zmiany położenia lub kształtu badanego obiektu. Metoda ta opiera się na zaawansowanych systemach optyczno-elektronicznych, w skład których wchodzą kamery wysokiej rozdzielczości, jak również szybkie kamery pozwalające na rejestrację obrazów podczas zdarzeń szybkozmiennych [5-7, $11,15,18]$. Wykorzystanie systemu DIC w badaniach doświadczalnych żelbetowych belek skręcanych pozwoliło na uzyskanie szeregu danych, które mogą służyć do walidacji modeli numerycznych badanych obiektów. System do pomiarów wizyjnych Q-450 umożliwił jednoczesny pomiar przemieszczeń ok. 2500 punktów znajdujących się na bocznej powierzchni belki. Zastosowanie w badaniach żelbetowych belek wspornikowych systemu DIC pozwoliło między innymi na określenie linii ugięcia belki oraz wartości odkształceń w każdej sekundzie badania, jak również obserwację rozwoju 
rys na badanej powierzchni belki w czasie badania, określenie przebiegu rys oraz pomiar kąta ich nachylenia w czasie, gdy rysy nie były jeszcze widoczne gołym okiem.

Symulacje numeryczne belek przeprowadzono za pomocą programu ATENA 3D - Studio. Do nieliniowej analizy belek żelbetowych wykorzystano modele betonu opisujące zależność $\sigma-\varepsilon \mathrm{w}$ złożonym stanie naprężeń bazujące na zaleceniach Model Code 2010 i Model Code 90 o podstawowych parametrach materiałowych ustalonych doświadczalnie. Model ten opisuje zachowanie się betonu w konstrukcjach zbrojonych ze szczególnym uwzględnieniem obniżenia wytrzymałości na ściskanie przy zarysowaniu, usztywniającym wpływem betonu w strefie rozciąganej po zarysowaniu oraz zmianą sztywności na ścinanie po zarysowaniu [2]. Zbrojenie zamodelowano wykorzystując model materiałowy „reinforcement”, zapewniający przyczepność między betonem i zbrojeniem. Na styku belka betonowa - stalowe elementy zamocowania umieszczono umowny materiał, którego zachowanie pod wpływem obciążenia miało odwzorowywać występujące minimalne niedokładności w wykonaniu belek oraz wystąpienie przemieszczeń na styku belka - stalowe elementy. W celu uzyskania zgodności modelu numerycznego z wynikami badań doświadczalnych parametry materiału określono na podstawie pomiarów przemieszczeń metodą cyfrowej korelacji obrazu, w trzech analizowanych kierunkach. Metoda DIC jest szczególnie przydatna w badaniach żelbetowych elementów konstrukcji, które charakteryzuje duża niejednorodność materiałowa. Wysoka dokładność i szerokie spektrum wyników uzyskanych z testów eksperymentalnych pozwalają na walidację warunków brzegowych założonych w modelu numerycznym, dzięki czemu warunki te odpowiadają rzeczywistemu zamocowaniu elementu podczas badań. 